\title{
Flow cytometric DNA index and karyotype in childhood lymphoblastic leukemia
}

\author{
Erik Forestier ${ }^{\mathrm{a}}$, Gösta Holmgren ${ }^{\mathrm{b}}$ and Göran Roos ${ }^{\mathrm{c}, *}$ \\ ${ }^{a}$ Department of Pediatrics, Umeå University, Sweden \\ ${ }^{\mathrm{b}}$ Department of Clinical Genetics, Umeå University, Sweden \\ ${ }^{\mathrm{c}}$ Department of Pathology, Umeå University, Sweden
}

Received 27 February 1998

Revised 3 October 1998

Accepted 15 October 1998

\begin{abstract}
Flow cytometric DNA-index $\left(\mathrm{DI}^{\mathrm{FCM}}\right)$ and karyotype were analysed in 82 consecutive children with acute lymphoblastic leukemia (ALL) during a 10 year period. A statistically significant correlation existed between modal chromosome number and $\mathrm{DI}^{\mathrm{FCM}}(p=0.009)$. $\mathrm{DI}^{\mathrm{FCM}}$ could reliably identify leukemias with $>51$ chromosomes, whereas only three out of 12 cases with modal chromosome numbers between $47-51$ were classified as aneuploid by $\mathrm{DI}^{\mathrm{FCM}}$. In the pseudodiploid group only one out of 20 leukemias had a $\mathrm{DI}^{\mathrm{FCM}}>1.0$. Five leukemias with a diploid karyotype showed an aneuploid $\mathrm{DI}^{\mathrm{FCM}}$ and in three patients the flow cytometric measurement revealed biclonality undetected by karyotyping. During treatment aneuploid clones could be detected by $\mathrm{DI}^{\mathrm{FCM}}$ in a substantial number of cases where the cytogenetic analysis was normal, and the opposite was also demonstrated in one case. $\mathrm{DI}^{\mathrm{FCM}}$ gave prognostic information, showing that cases with a DI $>1.12$ (corresponding to 51 chromosomes) had a superior outcome with treatment protocols today in use.
\end{abstract}

Keywords: Lymphoblastic leukemia, childhood, flow cytometry, DNA-index, karyotype, event free survival

\section{Introduction}

Acute lymphoblastic leukemia is the most common single malignant disease in childhood, and also the neoplasm with the most significant therapeutic progress during the last three decades [17]. This advance has been achieved by recognizing certain risk factors of prognostic importance giving the possibility to adjust the treatment accordingly. Intensification of treatment has weakened the impact of several prognostic factors, but still age $<$ one year and a white blood cell count $>100 \times 10^{9} / 1$ at diagnosis are strong predictors of treatment failure [6,11]. Also, certain translocations like $t(4 ; 11)$ and $t(9 ; 22)$ indicate unresponsiveness to conventional, intense cytostatic treatment $[1,5]$. In contrast, age between two and 10 years and hyperdiploid leukemia are recognized as independent indicators of good treatment outcome using standard protocols. It has also been suggested that this favourable group of patients could be treated equally well without the use of anthracyclines, epopodophyllotoxines and alkylating agents $[7,18]$. There is a covariation between modal chromosome number and traditional clinical risk factors, i.e., the group with $>51$ chromosomes is associated with favourable clinical features, but the hypodiploid group forming $1-3 \%$ of the cases has no distinct clinical features $[6,16]$. Therefore, when stratifying patients into future treatment protocols it will be important to reliably decide ploidy of the leukemic cells at diagnosis.

\footnotetext{
*Correspondence: Göran Roos, Department of Pathology, Umeå University, S-901 85 Umeå, Sweden. Tel.: +46 90785 1801; Fax: +46 90785 2829; E-mail: goran.roos@ pathol.umu.se.
} 
There are two major conventional techniques to investigate the ploidy of leukemic blasts. The traditional way is the karyotyping of cultured bone marrow cells with light microscopic counting of Giemsa banded metaphase chromosomes [20]. Ideally, $>20$ metaphases are studied and in order to call a numerical change clonal at least two cells showing the same abnormality are obligatory,and the demand is three cells in the case of whole chromosome losses. The low number of metaphases studied makes this technique fairly insensitive. The second approach is DNA content measurement by image analysis or by flow cytometry [12,21]. Since both techniques analyse a large number of cells they are more sensitive than karyotyping and for flow cytometry aneuploid clones representing only 2-3\% of the cell population studied can be reproducibly detected. By flow cytometry a coefficient of variation (cv) at $3 \%$ is achieved in the clinical routine which makes it difficult to detect near diploid abnormalities. The aim of the present study was to investigate the correlation between modal chromosome number obtained by karyotyping and DNA index obtained by flow cytometry $\left(\mathrm{DI}^{\mathrm{FCM}}\right)$ at diagnosis and during treatment of childhood ALL, and to compare these techniques as possible prognostic indicators.

\section{Material and methods}

\subsection{Material}

During a ten-year period (February 1987-February 1997) 82 children (age 0-17 years) were diagnosed as having acute lymphoblastic leukemia at the Department of Pediatrics in Umeå, constituting all children with this diagnosis in the 4 most northern counties in Sweden (population $10^{6}$ ).

\subsection{Immunophenotyping}

Mononuclear cells separated from bone marrow aspirates were used for immuno-phenotyping by flow cytometry (FACScan, Becton Dickinson Immunocytometry Systems, CA). Pre B-cell blasts were defined as CD19+ and/or CD20+ cells negative for surface immunoglobulin light chains, T-cell and myeloid markers. T-cell blasts were positive for pan T-cell markers as CD2 and/or CD7 and negative for B-cell and myeloid markers. Myeloid markers used were CD13 and CD33. Biphenotypic ALL was defined as positive for T- or B-cell and myeloid markers.

\subsection{DNA measurement by flow cytometry}

Estimation of the cellular DNA content was performed by flow cytometric analysis (FACScan) of mononuclear cells from bone marrow stained by propidium iodide according to Vindeløv [23]. Chicken and trout blood cells were used as internal controls. $\mathrm{DI}^{\mathrm{FCM}}$ was calculated as being the ratio between the leukemic G0/G1 peak and a diploid G0/G1 peak.

\subsection{Cytogenetic analysis}

Bone marrow cells were processed for karyotype analysis according to standard procedures. The chromosomes were G-banded with trypsin-Giemsa. Chromosomal abnormalities were identified and described according to the International System of Human Cytogenetic Nomenclature (ISCN) [8]. The DNA content of the leukemic clone was also calculated by summation of the DNA content of each individual chromosome in the karyotype [2,25]. Marker chromosomes were given a DNA-content according 
to the size of the chromosome. A DI based on this calculation was defined as the ratio between estimated DNA content of the leukemic clone and the DNA content of diploid cells, and was depicted DI ${ }^{\text {estimated }}$ $\left(\mathrm{DI}^{\mathrm{e}}\right)$.

\subsection{Treatment}

Two treatment protocols were used during the study period, denominated SBLG 86 and NOPHO 92, both being intense. The patients were stratified into 5 risk groups based on clinicohematological, immunological and cytogenetic findings at diagnosis, i.e., the standard, intermediate, high, very high and special risk groups [6].

\subsection{Statistical analysis}

The time to adverse event was defined as the interval between diagnosis and event. Patients who did not achieve remission were assigned a time of zero. Children who died in continuous complete remission (CCR) were assigned the time between diagnosis and death. Children in CCR were censored February 28, 1997. Statistical analyses were performed with SPSS statistical software for Macintosh (SPSS Inc., IL) [14]. Life tables were made using the Kaplan Meier method and difference in prognosis between subgroups were tested with the Log rank method [4]. The limit for significance was $p=0.05$.

\section{Results}

\subsection{Immunophenotype}

An evaluable immunophenotype was obtained in 80 leukemias (98\%), 71 of which were of pre B type, 5 had a T cell phenotype and 4 leukemias were biphenotypic. Two cases $($ no 7,20$)$ could not be evaluated properly. A summary of the immuno-phenotype data is given in Table 1.

\subsection{Cytogenetics}

Successful karyotyping was achieved in all 82 leukemias showing a pathological cytogenetic clone in 55 cases or $67 \%$ (48\% before 1992, and 86\% after 1991). An aneuploid clonal aberration was found in 35 cases, 12 of which had a modal chromosome number of 47-51 (No 11 with Downs syndrome), and 24 showing a modal number $>51$ (one case demonstrated near-triploidy). Pseudodiploidy, i.e., modal number 46 with deletions, translocations or marker chromosomes, was found in 20 leukemias $(25 \%)$. The karyotypes for all patients are shown in Table 1.

\section{3. $\mathrm{DI}^{\mathrm{FCM}}$ versus karyotype}

Adequate DNA histograms were obtained in all cases, and a $\mathrm{DI}^{\mathrm{FCM}}$ could be calculated. The correlation between modal chromosome number and $\mathrm{DI}^{\mathrm{FCM}}$ was signficant $(p=0.009)$ as shown in Fig. 1. Thirty two leukemias $(39 \%)$ had a DI $>1.0$. Five cases with flow cytometric aneuploidy had a diploid karyotype (no 2, 7, 20, 31 and 43), and one had a pseudodiploid karyotype (no 10) (Table 1). In the group with modal numbers between $47-51(n=11)$, two patients (no 18,23$)$ had a $\mathrm{DI}^{\mathrm{FCM}}>1.0$ and one patient (no 76) with two aneuploid clones $\left(\mathrm{DI}^{\mathrm{FCM}}=0.95\right.$ and 1.95 ) had a karyotype with several 
Table 1

Immunophenotype, flow cytometric DNA index $\left(\mathrm{DI}^{\mathrm{FCM}}\right)$, estimated DNA index $\left(\mathrm{DI}^{\mathrm{e}}\right)$ and karyotype for all patients in the present study

\begin{tabular}{|c|c|c|c|c|}
\hline No & Immunophenotype & $\mathrm{DI}^{\mathrm{FCM}}$ & $\mathrm{DI}^{\mathrm{e}}$ & Karyotype \\
\hline 1 & Pre B cell & 1 & & $48, X X, \operatorname{del}(11)(q 23),+8,+21$ \\
\hline 2 & Pre B cell & 1.20 & & $46, X Y$ \\
\hline 3 & Pre B cell & 1 & & $46, \mathrm{XX},-19,+\operatorname{mar}$ \\
\hline 4 & Pre B cell & 1 & & $46, X X$ \\
\hline 5 & Pre B cell & 1 & & $46, X X$ \\
\hline 6 & Pre B cell & 1 & & $46, X X$ \\
\hline 7 & Unclassified & 1.20 & & $46, X X$ \\
\hline 8 & Biphenotypic & 1 & & $46, X Y$ \\
\hline 9 & Pre B cell & 1.20 & & $52, X Y$,inc \\
\hline 10 & Pre B cell & 1.10 & & $46, X Y, t(4 ; 11)(q 21 ; q 23)$ \\
\hline 11 & Pre B cell & 1 & & $47, X Y,+21 c$ \\
\hline 12 & Pre B cell & 1 & & $46, X Y,+$ mar,inc \\
\hline 13 & Pre B cell & 1 & & $46, X X$ \\
\hline 14 & Pre B cell & 1 & & $46, X X$ \\
\hline 15 & Pre B cell & 1 & & $46, X X$ \\
\hline 16 & Pre B cell & 1.20 & & $55, \mathrm{XX}$,inc \\
\hline 17 & Pre B cell & 1 & & $46, X X$ \\
\hline 18 & Pre B cell & 1.05 & 1.01 & $47, \mathrm{XY},+$ mar \\
\hline 19 & Pre B cell & 1 & & $46, \mathrm{XX}, \mathrm{t}(4 ; 11)(\mathrm{q} 21 ; \mathrm{q} 23)$ \\
\hline 20 & Unclassified & 1.1 & & $46, X X$ \\
\hline 21 & Pre B cell & 1 & & $46, X Y$ \\
\hline 22 & Pre B cell & 1 & & $46, X X, t(1 ; 12)(p ? ; q ?), \operatorname{del}(11)(q 14)$ \\
\hline 23 & Pre B cell & 1 & & $46, \mathrm{XX},+$ mar,inc \\
\hline 24 & Pre B cell & 1.10 & 1.03 & $50, \mathrm{XY},+\mathrm{X},+\operatorname{add}(6)(\mathrm{q} ?),+17,+\operatorname{mar}$ \\
\hline 25 & Pre B cell & 1 & & $46, X X$ \\
\hline 26 & T-cell & 1 & & 46,XY,+mar,inc \\
\hline 27 & T-cell & 1 & & $46, X Y$ \\
\hline 28 & Pre B cell & 1 & & $46, X X$ \\
\hline 29 & Pre B cell & 1 & & $46, X Y$ \\
\hline 30 & Pre B cell & 1 & & $46, X Y$ \\
\hline 31 & Pre B cell & 1.30 & & $46, X X$ \\
\hline 32 & Pro B cell & 1 & & $46, X Y$ \\
\hline 33 & Pre B cell & 1 & & $46, X X$ \\
\hline 34 & Pre B cell & 1.40 & 1.45 & $68, \mathrm{XXX},+1,-5,+6,-7,-9,+11,+12,-15,-16,-17,+19,-20$,inc \\
\hline 35 & Pre B cell & 1 & & $46, X Y, t(7 ; 9)(p ? ; q ?),+X,-9$ \\
\hline 36 & Biphenotypic & 1 & & $48, \mathrm{XY},+21,+\mathrm{mar}$ \\
\hline 37 & Pre B cell & 1.17 & & $53, X Y$,inc \\
\hline 38 & Pre B cell & 1.21 & 1.21 & $56, X X,+X,+X,+3,+4,+9,+10,+13,+18,+19,+21$ \\
\hline 39 & Pre B cell & 1 & & $47, \mathrm{XY},+19, \mathrm{t}(1 ; 19)(\mathrm{q} 23 ; \mathrm{p} 13)$ \\
\hline 40 & Pre B cell & 1.11 & 1.07 & $52, \mathrm{XX},+4,+5,+10,+18,+20,+22$ \\
\hline 41 & Pre B cell & 1.15 & 1.1 & $53, \mathrm{XX},+4,+20,+$ mar,inc \\
\hline 42 & Pre B cell & $1.16 / 1.36$ & 1.15 & $55, \mathrm{XY},+4,+6,+10,+12,+19,+20,+22,+$ mar,inc \\
\hline 43 & Pre B cell & 1.12 & & $46, X Y$ \\
\hline 44 & Pre B cell & 1.16 & & $59, X Y$,inc \\
\hline
\end{tabular}


Table 1 (Continued)

\begin{tabular}{|c|c|c|c|c|}
\hline No & Immunophenotype & $\mathrm{DI}^{\mathrm{FCM}}$ & $\mathrm{DI}^{\mathrm{e}}$ & Karyotype \\
\hline 45 & Pre B cell & 1.22 & 1.21 & $57, \mathrm{XY},+3,+19,+21,+$ mar,inc \\
\hline 46 & Pre B cell & 1.22 & 1.14 & $52, X X,+X, \operatorname{add}(1)(\mathrm{q} ?),+4,+6,+9,+10,+14,-17,+21$ \\
\hline 47 & Pre B cell & 1.23 & 1.20 & $56, \mathrm{XY},+6,+10,+14,+17,+19,+20,+21,+3 \mathrm{mar}$ \\
\hline 48 & T-cell & 1 & & $47, \mathrm{XY}, \mathrm{t}(10 ; 14)(\mathrm{q} 24 ; \mathrm{q} 11)+\mathrm{mar}$ \\
\hline 49 & T-cell & 1 & & $46, \mathrm{XY}, \mathrm{t}(11 ; 14 ; 18)(\mathrm{p} 11 ; \mathrm{q} 11 ; \mathrm{q} 23-24)$ \\
\hline 50 & Pre B cell & 1.19 & 1.16 & $54, X X, \operatorname{add}(2)(\mathrm{q} ?),+6,+10,+11,+17,+18,+19,+21,+22$ \\
\hline 51 & Pre B cell & 1 & & $46, \mathrm{XY}, \operatorname{der}(12), \mathrm{t}(12 ; 14)(\mathrm{p} 12 ; \mathrm{q} 11)$ \\
\hline 52 & Pre B cell & 1.29 & 1.24 & $59, \mathrm{XY},+\mathrm{X},+\mathrm{Y},+4,+5,+6,+14,+15,+17,+18,+21,+21,+$ mar,inc \\
\hline 53 & Pre B cell & 1 & & $47, X Y, \operatorname{add}(5)(q 35)$ \\
\hline 54 & T-cell & 1 & & $46, \mathrm{XY}, \mathrm{t}(4 ; ?), \mathrm{t}(? ; 14) / 46, \mathrm{XY}, \mathrm{t}(7 ; ?)$ \\
\hline 55 & Pre B cell & 1 & & $47, X X,-X,+16, t(3 ; 9)(q 21 ; q 34),+\operatorname{mar}$ \\
\hline 56 & Pre B cell & 1 & & $46, X X$ \\
\hline 57 & Pre B cell & 1 & & $48, X X,+X, ?+21$ \\
\hline 58 & Pre B cell & 1.22 & 1.14 & $55, \mathrm{XX},+\mathrm{X},+3,+6,+10,+14,+18,+$ mar,inc \\
\hline 59 & Pre B cell & 1 & & $46, X Y$ \\
\hline 60 & Pre B cell & 1 & & $46, X Y, t(1 ; 19)(q 23 ; p 11), t(1 ; 15)(\mathrm{q} 11 ; \mathrm{p} 11), \operatorname{del}(6)(\mathrm{q} 21)$ \\
\hline 61 & Biphenotypic & 1 & & $46, X Y, t(2 ; 14)(\mathrm{q} 23 ; \mathrm{q} 32)$ \\
\hline 62 & Pre B cell & 1.15 & 1.12 & $54, \mathrm{XX},+\mathrm{X},+7,+18,+21,+$ mar,inc \\
\hline 63 & Pre B cell & 1.18 & 1.18 & $55, \mathrm{XX},+\mathrm{X},+5,+5,+6,+14,+17,+21,+21,+\operatorname{mar}$ \\
\hline 64 & Pre B cell & 1 & & $46, X Y$ \\
\hline 65 & Pre B cell & 1 & & $46, \mathrm{XY}, \operatorname{del}(9)(\mathrm{p} 1.1), \operatorname{del}(17)(\mathrm{p} 1.1)$ \\
\hline 66 & Pre B cell & 1 & & $46, \mathrm{XX}, \mathrm{t}(1 ; 19)(\mathrm{q} 23 ; \mathrm{p} 13)$ \\
\hline 67 & Pre B cell & 1 & & $46, X X, \operatorname{del}(1)(q 22 q 24)$ \\
\hline 68 & Pre B cell & 1.13 & 1.09 & $54, \mathrm{XY},+\mathrm{X},+4, \operatorname{del}(10)(\mathrm{p} 11),+21,+21,+$ mar,inc \\
\hline 69 & Biphenotypic & 1 & & $46, X X, \operatorname{del}(6)(q 21)$ \\
\hline 70 & Pre B cell & 1 & & $46, X X$ \\
\hline 71 & Pre B cell & 1.18 & & $55, \mathrm{XX},+6,+14,+21,+22,+$ mar,inc \\
\hline 72 & Pre B cell & $1.21 / 1.30$ & 1.24 & $56, \mathrm{XX},+2,+3,+6,+8,+10,+13,+14,-16,-17,+19,+20,+21,+22,+\operatorname{mar}$ \\
\hline 73 & Pre B cell & 1 & & $46, X X$ \\
\hline 74 & Pre B cell & 1 & & $46, \mathrm{XY}, \mathrm{t}(3 ; 12)(\mathrm{p} 11 ; \mathrm{p} 13.2)$ \\
\hline 75 & Pre B cell & 1.16 & 1.09 & $53, X Y,+X,+4,+6,+14,+17,+18,+21$ \\
\hline 76 & T-cell & $0.95 / 1.95$ & 0.96 & $47, X Y, \operatorname{del}(2)(\mathrm{p} 22),-5, \operatorname{del}(11)(\mathrm{q} 23), \operatorname{del}(16)(\mathrm{q} 22),+19,+\operatorname{mar}$ \\
\hline 77 & Pre B cell & 1.16 & 1.15 & $55, \mathrm{XX},+6,+14,+17,+18,+19,+21,+21,+2 \mathrm{mar}$ \\
\hline 78 & Pre B cell & 1 & & $46, \mathrm{XX}, \mathrm{t}(11 ; 19)(\mathrm{q} 23 ; \mathrm{p} 13)$ \\
\hline 79 & Pre B cell & 1 & & $47, \mathrm{XY}, \operatorname{del}(3)(\mathrm{p} ?), \operatorname{add}(3)(\mathrm{q} ?),+5, \mathrm{t}(9 ; 22)(\mathrm{q} 34 ; \mathrm{q} 11), \operatorname{add}(14)(\mathrm{q} ?)$ \\
\hline 80 & Pre B cell & 1 & & $46, X Y, t(4 ; 11)(q 21 ; q 23)$ \\
\hline 81 & Pre B cell & 1.12 & 1.13 & $53, \mathrm{XX},+\mathrm{X},+6,+8,+14,+17,+$ mar,inc \\
\hline 82 & Pre B cell & 1.18 & 1.15 & $54, \mathrm{XX},+\mathrm{X},+\mathrm{X},+5,+10,+10,+13,+18,+21$ \\
\hline
\end{tabular}

No: patient number in chronologic order; $\mathrm{DI}^{\mathrm{FCM}}$ : flow cytometric DNA index; $\mathrm{DI}^{\mathrm{e}}$ : estimated DNA index; Karyotype: main line bone marrow karyotype.

deletions. In three patients (no $42,72,76$ ) the flow cytometric analysis revealed two different clones at diagnosis undetected by cytogenetics. In all three patients the second clone was small and only found in bone marrow but not in peripheral blood samples. More than two separate clones was not demonstrated. When combining $\mathrm{DI}^{\mathrm{FCM}}$ and karyotype, 42 leukemias (51\%) were shown to be hyperdiploid. 


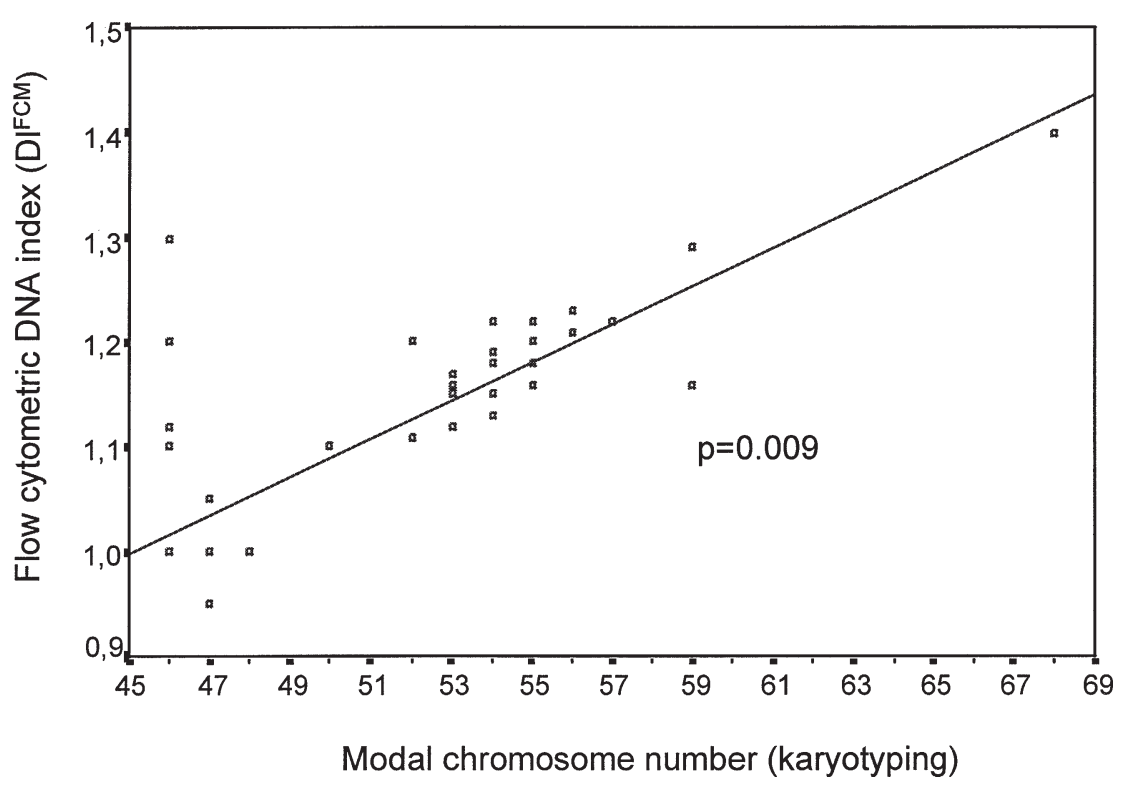

Fig. 1. Correlation between flow cytometric DNA index $\left(\mathrm{DI}^{\mathrm{FCM}}\right)$ and modal chromosome number obtained by karyotyping.

In patients treated on the NOPHO 92 protocol used for patients diagnosed after 1991, bone marrow examination was performed on treatment day 15 and day 29 . Nineteen leukemias had a $\mathrm{DI}^{\mathrm{FCM}}>1.0$. In 7 of 19 cases (37\%) the $\mathrm{DI}^{\mathrm{FCM}}$ detected an aneuploid leukemic clone at day 15 (3/7 traditional standardrisk), and at day 29 still 4 (21\%) remained positive (3/4 traditional standardrisk), whereas the karyotype in all these follow-up samples were diploid. The fraction of aneuploid cells on day 15 and 29 samples varied from 3 to $20 \%$ of all cells as judged from the DNA histograms. Consecutive $\mathrm{DI}^{\mathrm{FCM}}$ analyses from one of these patients are presented in Fig. 2. One patient showed a persistent leukemic clone at treatment day 43 and 50.

\section{4. $\mathrm{DI}^{\mathrm{FCM}}$ versus $\mathrm{DI}^{\mathrm{e}}$}

To test if the DI ${ }^{\mathrm{FCM}}$ really measured the same clone that was diagnosed with cytogenetics, 22 leukemias with the higest quality aneuploid karyotypes and corresponding DNA histograms were chosen. In these cases $\mathrm{DI}^{\mathrm{e}}$ was calculated and compared with the results from the flow cytometric analysis. A highly significant correlation $(p=0.01)$ was found as shown in Fig. 3.

\subsection{Patients no 34 and 46}

Patient no 34 had a clinical and morphological relapse during maintenance therapy and compared to the diagnostic sample a change occurred in immunophenotype, karyotype and $\mathrm{DI}^{\mathrm{FCM}}$ as detailed in Table 2.

Patient no 46 showed after 8 mo and during maintenance therapy (oral methotrexate and 6-mercaptopurin) with intensification (alternating high dose methotrexate $\left(5 \mathrm{~g} / \mathrm{m}^{2}\right)$ and vincristine/prednisolon) a drop in haemoglobin and thrombocyte values. The bone marrow showed morphological and phenotypic remission and a $\mathrm{DI}^{\mathrm{FCM}}$ of 1.0. Two out of 20 metaphases showed a hyperdiploid karyotype with a modal chromosome number of 59 and several trisomias also seen in the diagnostic bone marrow. Bone marrow 


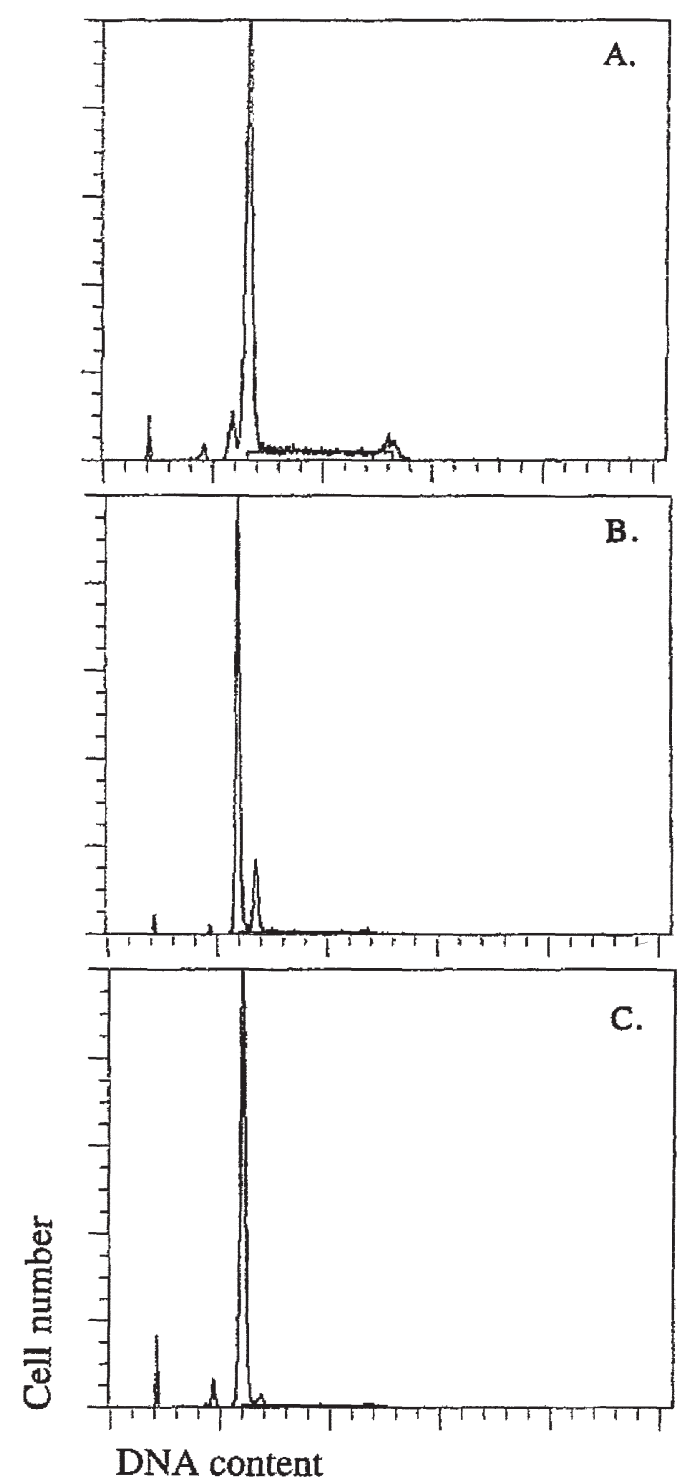

Fig. 2. Flow cytometric DNA index $\left(\mathrm{DI}^{\mathrm{FCM}}\right)$ analysis on bone marrow samples from patient no 81 at diagnosis, treatment day 15 and 29.

examination two months later showed one hyperdiploid out of 30 metaphases, with no other evidence of disease. Maintenance therapy continued and the patient is still in CCR, 12 mo off therapy (Table 3).

\subsection{Survival}

To test the prognostic impact of ploidy alone measured by the two different methods the patients were subdivided into three groups using cut off points at $\mathrm{DI}^{\mathrm{FCM}} 1.0$ and 1.12 , corresponding to 46 and 51 chromosomes. There was a statistically significant difference in survival between the three ploidy groups $(p=0.03)$ measured by $\mathrm{DI}^{\mathrm{FCM}}$ but not with karyotyping (not significant, not shown in figures). The 


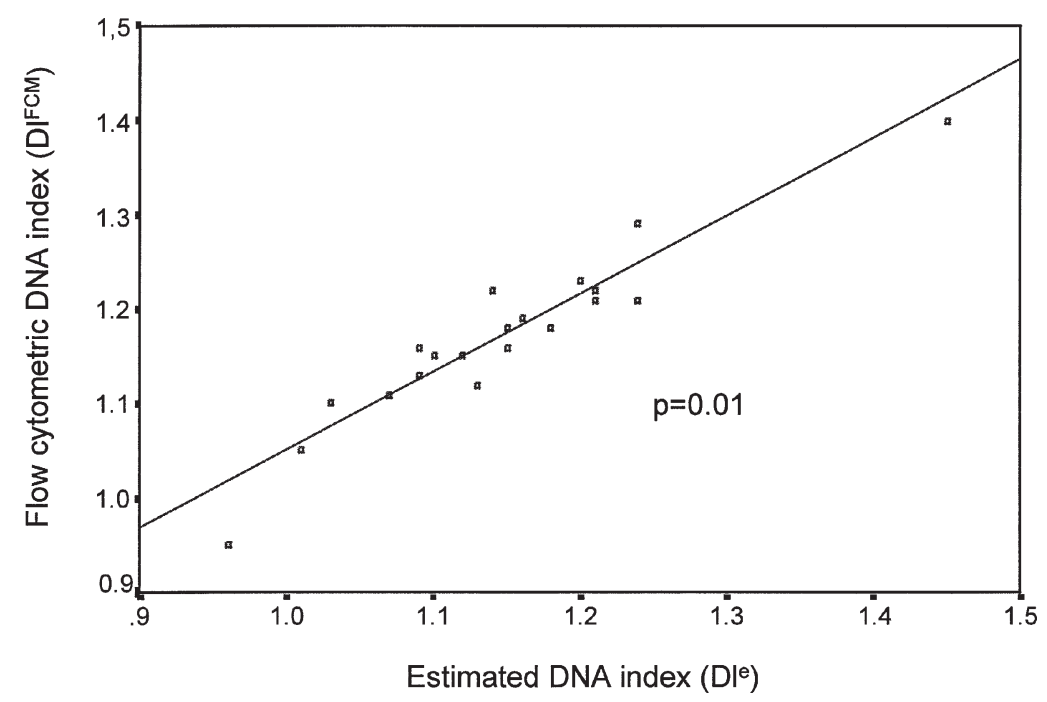

Fig. 3. Correlation between flow cytometric DNA index $\left(\mathrm{DI}^{\mathrm{FCM}}\right)$ and DNA-index estimated from karyotype data $\left(\mathrm{DI}^{\mathrm{e}}\right)$.

Table 2

Data from karyotyping, immunophenotyping and flow cytometric DNA index $\left(\mathrm{DI}^{\mathrm{FCM}}\right)$ measurements in diagnostic and follow up samples from patient no 34

\begin{tabular}{rllll}
\hline Time & Morphology & Immunophenotype & $\mathrm{DI}^{\mathrm{FCM}}$ & Karyotype \\
\hline 0 & ALL L3 & Pre B cell, HLA DR, 34, 19, 10, 20w & 1.4 & $68, \mathrm{XXX},+1,-5,+6,-7,-9,+11,+12,-15,-16$, \\
& & & \multicolumn{2}{c}{$-17,+19,-20$, inc } \\
56 & Remission & nd & nd & $46, \mathrm{XX}$ \\
175 & Remission & nd & nd & $46, \mathrm{XX}$ \\
581 & Relapse L3 & Pre B cell, HLA DR, 19, 10w, 13w & 1.32 & $63, \mathrm{XX}, \mathrm{t}(5 ; 7)(\mathrm{p} 14 ; \mathrm{q} 11)$, inc \\
612 & Remission & nd & 1.0 & $46, \mathrm{XX}$ \\
630 & Relapse pb & nd & 1.34 & nd \\
630 & Relapse L3 & Pre B cell, HLA DR, 19,13 & 1.34 & nd \\
658 & Remission & nd & 1.0 & $46, \mathrm{XX}$ \\
693 & Remission & nd & nd & no metaphases \\
711 & Remission & nd & 1.0 & no metaphases \\
\hline
\end{tabular}

Time: time from diagnosis in days; pb: peripheral blood; w: weak positivity; nd: not done; $\mathrm{DI}^{\mathrm{FCM}}$ : flow cytometric DNA index; Karyotype: main line bone marrow karyotype.

survival statistics included all children irrespective of age and risk group (observation time 2-117 mo). Survival curves are shown in Fig. 4.

\section{Discussion}

It has repeatedly been shown that hyperdiploid ALL has a better prognosis than pseudodiploid and diploid ALL [6,18]. There is also evidence that especially hypodiploid, but also triploid and tetraploid ALL cases have a worse prognosis [15-18]. New therapy regimes seems to decrease the impact of triand tetraploidy on prognosis but hypodiploidy still remains a bad prognostic factor $[6,16]$. The standard 
Table 3

Data from karyotyping and flow cytometric DNA index $\left(\mathrm{DI}^{\mathrm{FCM}}\right)$ measurements in diagnostic and follow up samples from patient no 46

\begin{tabular}{clllcc}
\hline Time & Morphology & Immunophenotype & $\mathrm{DI}^{\mathrm{FCM}}$ & Karyotype & Metaphases \\
\hline 0 & ALL LI & DR, 34, 19,10 & 1,22 & $52, \mathrm{XX},+\mathrm{X}, \operatorname{add}(1)(\mathrm{q} ?),+4,+6,+9$, & \\
& & & $+10,+14,-17,+21$ & \\
21 & Remission & nd & & \\
32 & Remission & nd & & \\
239 & Remission & 1 & $59, \mathrm{XX},+1,+4,+6,+8,+9,+12,+13$, & \\
& & & $+14,+15,+19,+20,+21,+22$ & $2 / 20$ \\
252 & Remission & 1 & $56, \mathrm{XX},+\mathrm{X},+2,+6,+11,+12,+14$, & \\
& & & $+19,+21,+22$ & \\
371 & Remission & 1 & & \\
392 & Remission & nd & & \\
473 & Remission & 1 & & \\
933 & Remission & & 1 & & \\
\hline
\end{tabular}

Time: time from diagnosis in days; nd: not done; $\mathrm{DI}^{\mathrm{FCM}}$ : flow cytometric DNA index; Karyotype: main line bone marrow karyotype.

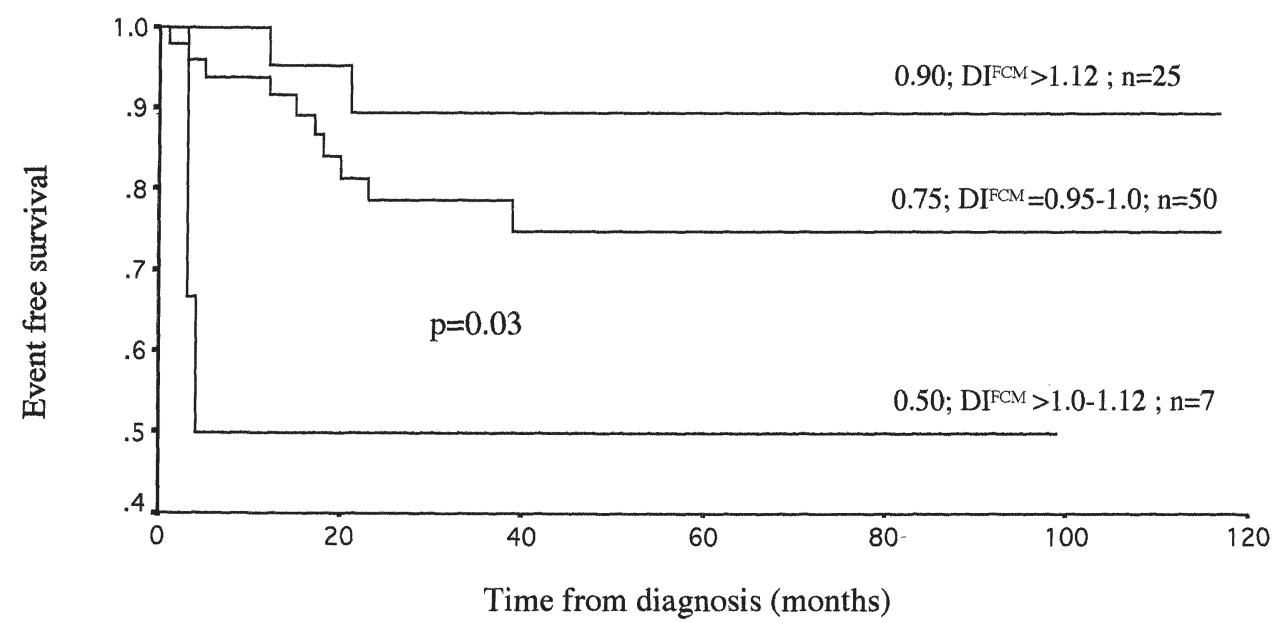

Fig. 4. Probability of event free survival. Cut off points were set at flow cytometric DNA indices $\left(\mathrm{DI}^{\mathrm{FCM}}\right)=1.0$ and 1.12.

technique to evaluate ploidy is metaphase karyotyping but also DNA content measurement by flow cytometry can be used with high accuracy as demonstrated in this report. Successful karyotyping needs living cells spontaneously entering mitosis, and counting of metaphase chromosomes is performed by light microscopy. Flow cytometric DNA analysis is easy to perform and all cells are included in the DNA-histogram unless electronic gates are used for selective analysis of specific cells, and the method is not dependent on cycling cells. The flow cytometric method has the ability to discover small aneuploid clones constituting a low percent of the total cell population [10]. The capacity to detect small DNA content abnormalities is dependent on the quality of the sample, the staining technique and the instrument used. The smallest aberration we could discover in this study was the addition of a marker chromosome with a size corresponding to chromosome 4 . On the other hand, traditional karyotyping identifies smaller structural and numerical DNA changes. 
In the present study evaluable karyotypes and $\mathrm{DI}^{\mathrm{FCM}}$ values were obtained in all patients, as previously shown for leukemias and solid tumors [12,13,19,21,22]. We could demonstrate a highly significant correlation between the two methods, although the $\mathrm{DI}^{\mathrm{FCM}}$ analysis uncovered more hyperdiploid patients than was seen with karyotyping. All 5 cases with diploid karyotypes and $\mathrm{DI}^{\mathrm{FCM}}>1.0$ were found in samples obtained between 1987 to 1992, during which time pathological karyotypes were found in $48 \%$ of the cases. Two of these 5 patients showed single metaphases with modal numbers corresponding to the $\mathrm{DI}^{\mathrm{FCM}}$ values, indicating that the discrepancy was due to less optimal karyotyping. After $199286 \%$ of the leukemias demonstrated abnormal karyotypes. Thus, a considerable improvement in performing karyotyping was achieved during the period of study. The $\mathrm{DI}^{\mathrm{FCM}}$ technique was poor in discovering leukemic clones with modal numbers between $47-50$ as well as pseudodiploid clones. No patient in our series had a hypodiploid karyotype, but one patient with a near diploid modal number and several deletions had a $\mathrm{DI}^{\mathrm{FCM}}$ and $\mathrm{DI}^{\mathrm{e}}$ of $<1.0$ (Table 1).

Both at diagnosis and during induction treatment we repeatedly found $\mathrm{DI}^{\mathrm{FCM}}$ to be more sensitive than karyotyping in discovering small aneuploid clones. Two patients were shown by karyotyping to have undetected biclonality at diagnosis and in $>20 \%$ of the aneuploid patients the abnormal clone was revealed by $\mathrm{DI}^{\mathrm{FCM}}$ during the first month of induction therapy but showed a diploid karyotype. In at least one of these cases the aneuploid clone seemed to lack S and G2/M phase cells. During induction treatment phase- and cycle-specific drugs are used and the bone marrow is often very hypoplastic, which is a probable explanation for the negative cytogenetic results day 15 and 29. The finding of a persistant abnormal clone in a substantial proportion of patients during induction therapy, most of which (75\%) were standard risk patients is somewhat contradictory to data from studies using molecular genetic techniques for quantitation of residual disease [24].

Only one patient sample had a modal number $>50$ and a $\mathrm{DI}^{\mathrm{FCM}}$ of 1.0 , and this observation was made during treatment when the patient according to other parameters was in complete remission. Usually the identification of a pathological cytogenetic clone is equal to a relapse, but our patient was in all other laboratory tests in remission. The traditional maintenance therapy was continued and the patient is now, 12 mo off therapy, still in complete remission. Probably the fraction of leukemic cells was under the limit of detection for the $\mathrm{DI}^{\mathrm{FCM}}$ technique, and by chance these metaphases appeared in the cytogenetic analysis.

The proportion of hyperdiploid leukemias measured by combining $\mathrm{DI}^{\mathrm{FCM}}$ and cytogenetics was somewhat higher $(51 \%)$ in this study than earlier reported [6]. With good conventional cytogenetics a pathological clone is found in at least $80 \%$ of the cases and the hyperdiploid part is usually $30-45 \%$. The reason for this higher frequency in our study could be a variation due to the small material or the superior ability of $\mathrm{DI}^{\mathrm{FCM}}$ to discover hyperdiploid leukemias with modal numbers over 50 . It has also been postulated that there are geographical differences in the frequency of leukemic genetic aberrations $[3,9]$, and this study, in opposition to most published studies, is truly population based. It is probably easier to identify both the hypo- and hyperdiploid group with $\mathrm{DI}^{\mathrm{FCM}}$ than with traditional metaphase karyotyping $[17,21]$, because the latter method is more laborious and more dependant on laboratory skills and the availability of living cells.

Even with contemporary treatment protocols it is generally accepted that the clonal karyotype have a prognostic impact. Leukemia-specific rearrangements such as $\mathrm{t}(4 ; 11), \mathrm{t}(9 ; 22)$ and hypodiploidy $(<45$ chromosomes) are predictors of poor outcome and modal number $>51$ indicate a good prognosis, though different dividing points have been suggested $[12,18]$. In order to enable comparison between the $\mathrm{DI}^{\mathrm{FCM}}$ and karyotype the patients were divided into three groups based on main line modal number. A statistically significant difference in survival was found using the $\mathrm{DI}^{\mathrm{FCM}}$ approach, a difference not found using 
modal numbers obtained by karyotyping. Thus, in this material the $\mathrm{DI}^{\mathrm{FCM}}$ technique was better than karyotyping in defining the group of hyperdiploid patients with favourable prognosis. This difference was however mainly caused by the inadequate cytogenetic performance during the first investigation period. Our data indicate that karyotyping can not be used for ploidy based prognostic purposes until a sucess rate of $80 \%$ pathological cases has been achieved.

The main conclusions of this study are that $\mathrm{DI}^{\mathrm{FCM}}$ is a sensitive and reliable method to identify hyperdiploid leukemia ( $>51$ chromosomes) and that it measures the dominant clone in the bone marrow at diagnosis. It does not distinguish the group of patients with 47-51 chromosomes nor the pseudodiploid group. In our population the proportion of hyperdiploid leukemias were higher than usually reported. To rely upon karyotyping when deciding ploidy of leukemias you must have a very high quality cytogenetics. We can also show that ploidy measured by flow cytometry at diagnosis gives useful prognostic information in a small, population based single institution study. $\mathrm{DI}^{\mathrm{FCM}}$ can identify biclonality at diagnosis and distinguish persistent aneuploid leukemia during induction therapy when standard cytogenetics and morphology fail to do so. A surprisingly high proportion of good risk leukemias demonstrate these persistent clones during the first 4 weeks of treatment.

\section{Acknowledgements}

Financial support was obtained from the Swedish Children Cancer Fund, the Swedish Cancer Society, the Samaritens Research Foundation in Stockholm, Lions Cancer Research Foundation, Umeå and Children's Cancer Association in Umeå.

\section{References}

[1] D.C. Arthur, C.D. Bloomfield, L.L. Lindquist and M.E. Nesbit Jr., Translocation 4,11 in acute lymphoblastic leukemia: clinical characteristics and prognostic significanse, Blood 59 (1982), 96-99.

[2] A.V. Carrano, J.W. Gray, R.G. Langlois, K.J. Burkhart-Schultz and M.A. Van-Dilla, Measurement and purification of human chromosomes by flow cytometry and sorting, Proc. Natl. Acad. Sci. 76 (1979), 1382-1384.

[3] L.C. Chan, Ha Sy, L.M. Ching, C.P. Lee, Y.L. Lau, P. Yuen and N.K. Leung, Cytogenetics and immunophenotypes of childhood acute lymphoblastic leukemia in Hong Kong, Cancer Cytogenetics 76 (1994), 118-124.

[4] D.R. Cox, Regression models and life tables, J. Royal Stat. Soc. (B) 34 (1972), 187-220.

[5] W. Crist, A. Carroll, J. Shuster, J. Jackson, D. Head, M. Borowitz, F. Behm, M. Link, P. Steuber and A. Ragab, Philadelphia chromosome positive childhood acute lymphoblastic leukemia: clinical and cytogenetic characteristics and treatment outcome. A Pediatric Oncology Group study, Blood 76 (1990), 489-494.

[6] E. Forestier, G. Gustafsson, A. von Heideman, S. Heim, O. Hernell, F. Mitelman, I. Nordenson, B. Swolin and S. Söderhäll, Prognostic impact of bone marrow karyotype in childhood acute lymphoblastic leukemia: Swedish experience, Acta Padiatrica (1997) (in press).

[7] M.B. Harris, J. Shuster, A. Caroll, A.T. Look, M.J. Borowitz, W.M. Crist, R. Nitschke, J. Pullen, CP. Steuber and V.J. Land, Trisomy of leukemic cell chromosomes 4 and 10 identifies children with B-progenitor cell acute lymphoblastic leukemia with a very low risk of treatment failure, A Pediatric Oncology Group study, Blood 79 (1992), 3316-3324.

[8] ISCN. An International System for Human Cytogenetic Nomenclature, Published in collaboration with Cytogenetic Cell Genet, Karger, Basel, Switzerland, 1985.

[9] B. Johansson, F. Mertens and F. Mitelman, Geographic heterogeneity of neoplasia-associated chromosome aberrations, Genes Chromosomes Cancer 3 (1991), 1-7.

[10] L.G. Koss, B. Czerniak, F. Herz and R.P. Wersto, Flow cytometric measurements of DNA and other cell components in human tumors: a critical apprasial, Hum. Pathol. 20 (1989), 528-548.

[11] F. Lampert, J. Harbott, J. Ritterbach, G. Schellong, J. Ritter, U. Creutzig, H. Riehm and A. Reiter, Karyotypes in acute childhood leukemias may lose prognostic significance with more intensive and specific chemotherapy, Cancer Genet. Cytogenet. 54 (1991), 277-279. 
[12] A.T. Look, S.L. Melvin, D.L. Williams, G.M. Brodeur, G.V. Dahl, D.K. Kalwinsky, S.B. Murphy and A.M. Mauer, Aneuploidy and percentage of S-phase cells determined by flow cytometry correlate with cell phenotype in childhood acute leukemia, Blood 60 (1982), 959-967.

[13] N. Mandahl, B. Baldetorp, M. Fernö, M. Åkerman, A. Rydholm, S. Heim, H. Willen, D. Killander and F. Mitelman, Comparative cytogenetic and DNA flow cytometric analysis of 150 bone and soft-tissue tumors, Int. J. Cancer $\mathbf{5 3}$ (1993), 358-364.

[14] M.J. Nourusis, SPSS Statistical Software, SPSS Inc., Chicago, 1994.

[15] C.H. Pui, A.J. Carroll, D. Head, S.C. Raimondi, J.J. Schuster, W.M. Christ, M.P. Link, M.J. Borowitz and D.J. Behm, Near-triploid and near tetraploid acute lymphoblastic leukemia of childhood, Blood 76 (1990), 590-596.

[16] C.H. Pui, A.J. Carroll, S.C. Raimondi, V.J. Land, W.M. Crist, J.J. Schuster, D.L. Williams, D.J. Pullen, M.J. Borowitz, F.G. Behm and A.T. Look, Clinical presentation, karyotypic characterization, and treatment outcome of childhood acute lymphoblastic leukemia with near haploid and hypodiploid < 45 line, Blood 75 (1990), 1170-1177.

[17] C.H. Pui, Childhood leukemias, N. Engl. J. Med. 332 (1995), 1618-1630.

[18] S.C. Raimondi, C.H. Pui, M.L. Hancock, F.G. Behm, L. Filatov and G.K. Rivera, Heterogeneity of hyperdiploid (51-67) childhood acute lymphoblastic leukemia, Leukemia 10 (1996), 213-224.

[19] S. Rapi, A. Caldini, A. Fanelli, P. Berti, E. Lisi, E. Anichini, R. Caligiani, F. Sbernini, G. Taddei, A. Amorosi, D. Villari and T. Susini, Flow cytometric measurement of DNA content in human solid tumors: a comparison with cytogenetics, Cytometry 26(3) (1996), 192-197.

[20] L.M. Secker-Walker, S.D. Lawler and R.M. Hardisty, Prognostic implications of chromosomal findings in acute lymphoblastic leukaemia at diagnosis, Br. Med. J. 2 (1978), 1529-1530.

[21] L.A. Smets, R. Slater, E.R. van Wering, A. van der Does van der Berg, A.A. Hart, A.J. Veerman and W.A. Kemps, DNA index and \% S-phase cells determined in acute lymphoblastic leukemia of children: a report from studies ALL V, ALL VI, and ALL VII (1979-1991) of the Dutch childhood leukemia study group and the Netherlands workgroup on cancer genetics and cytogenetics, Med. Pediatr. Oncol. 25 (1995), 437-444.

[22] M. Tarkkanen, S. Nordling, T. Bohling, A. Kivioja, E. Karaharju, J. Szymanska, I. Elomaa and S. Knuutila, Comparison of cytogenetics, interphase cytogenetics, and DNA flow cytometry in bone tumors, Cytometry 26(3) (1996), 185-191.

[23] L.L. Vindelov, I.J. Christensen and N.I. Nissen, A detergent-trypsin method for the preparation of nuclei for flow cytometric DNA analysis, Cytometry 3(5) (1983), 323-327.

[24] R. Wasserman, N. Galili, Y. Ito, J.H. Silber, B.A. Reichard, S. Shane, R.B. Womer, B. Lange and G. Rovera, Residual disease at the end of induction therapy as a predictor of relapse during therapy in childhood B lineage acute lymphoblastic leukemia, J. Clin. Oncol. 10 (1992), 1879-1888.

[25] Workshop in cytogenetics in solid tumors, Tucson, AZ, 1991. 


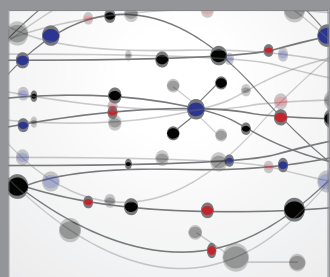

The Scientific World Journal
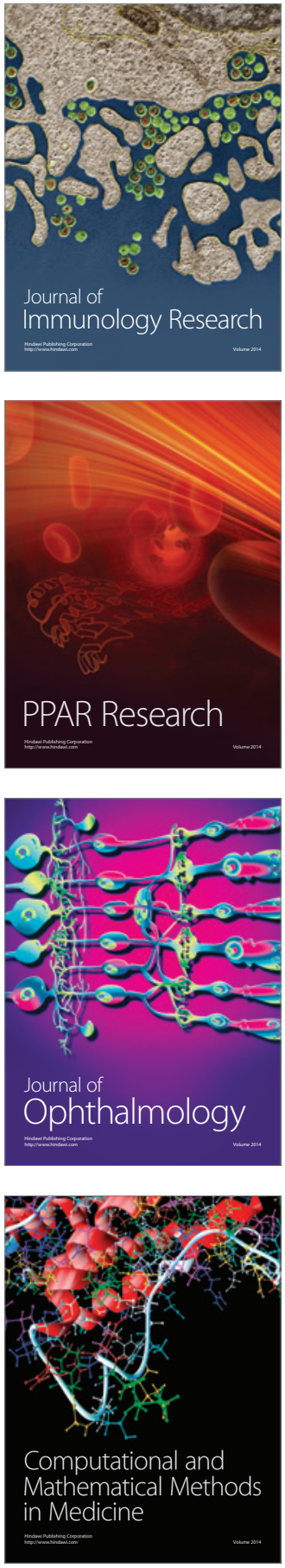

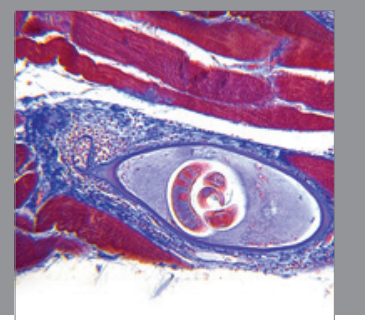

Gastroenterology

Research and Practice
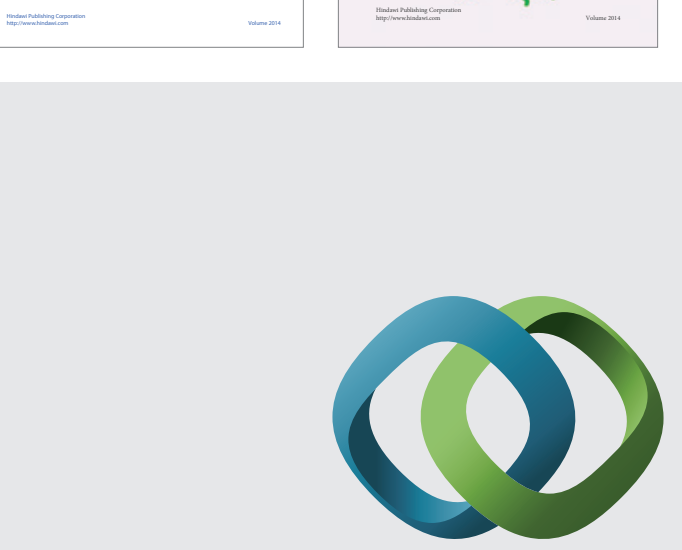

\section{Hindawi}

Submit your manuscripts at

http://www.hindawi.com
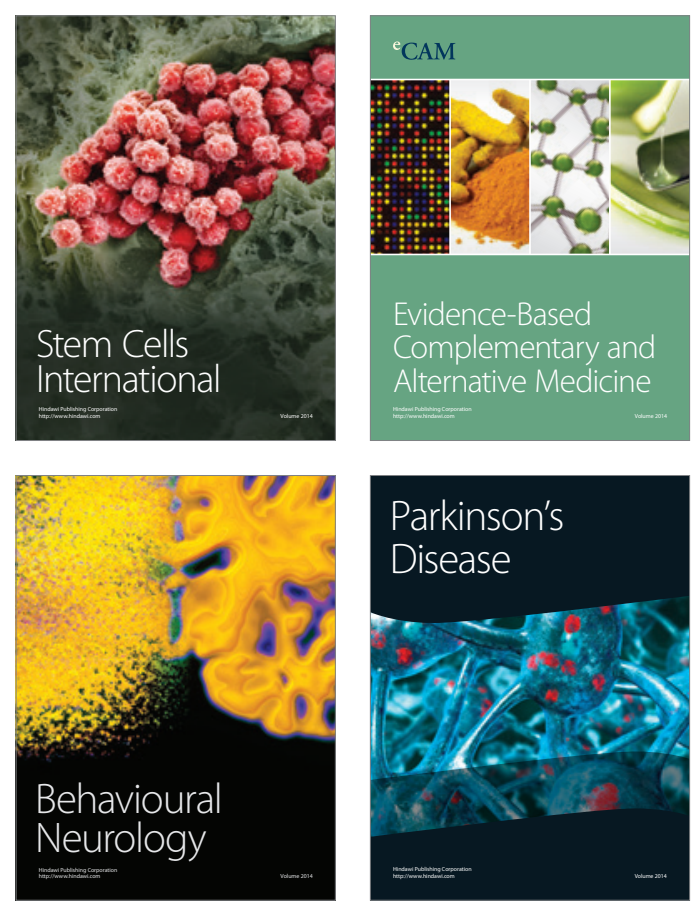

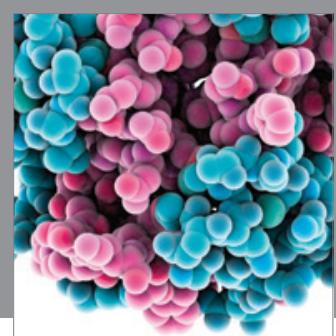

Journal of
Diabetes Research

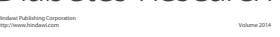

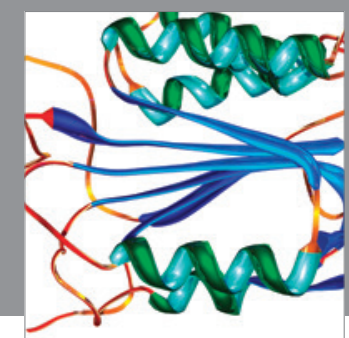

Disease Markers
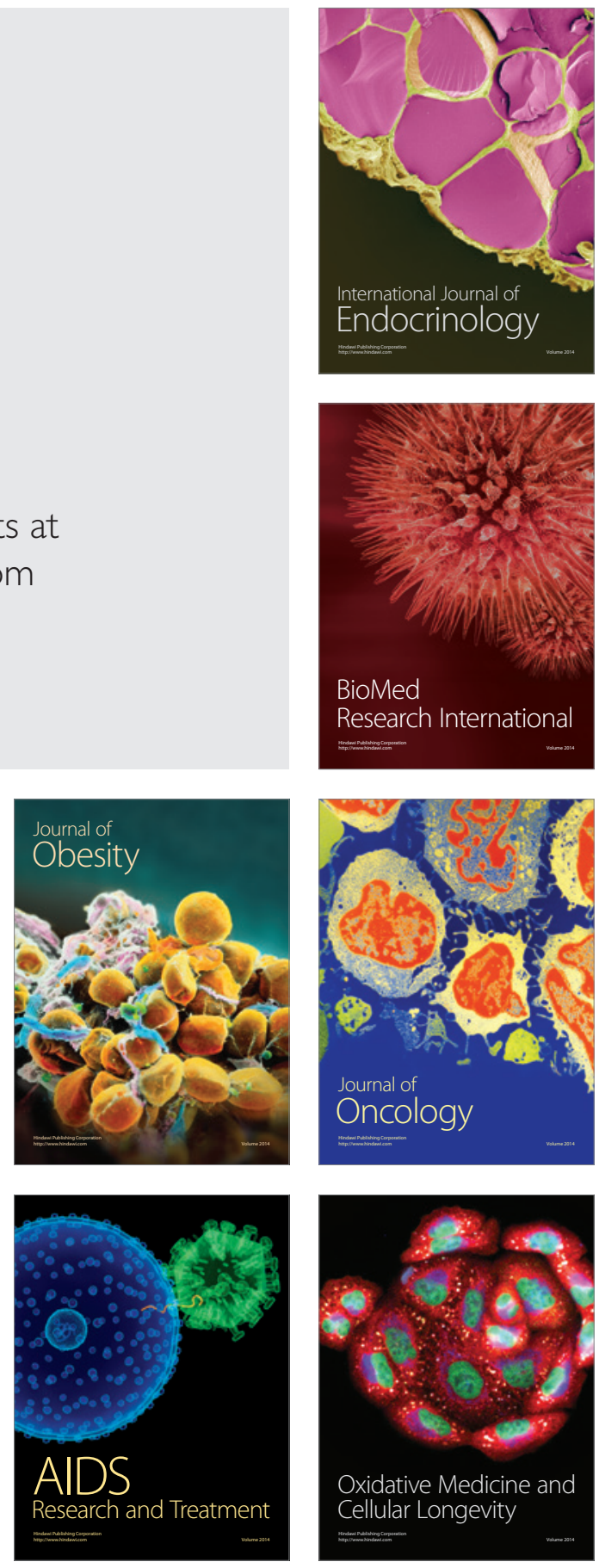